\title{
Colostrum composition of Santa Inês sheep and passive transfer of immunity to lambs
}

\author{
A. C. Alves, ${ }^{*}$ N. G. Alves, ${ }^{*} \dagger^{1}$ I. J. Ascari, ${ }^{*}$ F. B. Junqueira, $\dagger$ A. S. Coutinho, ${ }^{*}$ R. R. Lima, $\ddagger$ J. R. O. Pérez, $\dagger$ \\ S. O. De Paula,§ I. F. Furusho-Garcia,† and L. R. Abreu\# \\ *Department of Veterinary Medicine, \\ †Department of Animal Science, and \\ ‡Department of Exact Sciences, Federal University of Lavras, Lavras, 37200-000, Minas Gerais, Brazil \\ §Department of General Biology, Federal University of Viçosa, Viçosa, 36571-000, Minas Gerais, Brazil \\ \#Department of Food Sciences, Federal University of Lavras, Lavras, 37200-000, Minas Gerais, Brazil
}

\begin{abstract}
This study aimed to analyze the chemical composition and the IgG concentration of the colostrum, transitional milk, and mature milk of Santa Inês ewes as well as the transfer of passive immunity to lambs. Thirty-two pregnant ewes and 38 lambs were used. Ewes were milked immediately after lambing and at 12 , $24,36 \mathrm{~h}$ and $10 \mathrm{~d}$ postpartum. Colostrum was provided to the lambs at $40 \pm 15$ min (mean \pm SE) after birth and then at 30-min intervals for obtaining the intake closest to $10 \%$ of body weight, and transitional milk was provided ad libitum. Blood from the lambs was collected $36 \mathrm{~h}$ after birth for measuring the serum concentrations of IgG, total protein, albumin, and gammaglobulin. The production was lower in primiparous than in multiparous ewes with body condition score (BCS) $<2.75$, but did not differ between primiparous and multiparous with $\mathrm{BCS} \geq 2.75$ (interaction parity and BCS). The IgG concentration and fat, protein, lactose, and defatted dry extract percentages were not affected by the BCS of the ewe at lambing or by the parity. The total solids percentage in the colostrum was higher in ewes with BCS $<2.75$ (interaction BCS and time). The production and the protein, total solid, and defatted dry extract percentages showed quadratic behavior, the fat percentage decreased linearly, and the lactose percentage increased linearly with time postpartum. The IgG concentration in the colostrum was not correlated with the ewe's weight or BCS at the time of lambing. Moreover, the parity, the BCS, the ewe's type of gestation, and the lamb's sex did not influence the serum concentrations of $\operatorname{IgG}$, total protein, albumin, and gamma-globulin in lambs. Adequate passive immune transfer (PIT) was observed in lambs for which
\end{abstract}

Received January 29, 2014.

Accepted February 3, 2015.

${ }^{1}$ Corresponding author: nadja@dzo.ufla.br the IgG intake was higher than 30 g. Failure in PIT was observed in $39.5 \%$ of lambs when considering a serum $\mathrm{IgG}$ concentration lower than $15 \mathrm{mg} / \mathrm{mL}$ and in $21 \%$ when considering a serum total protein concentration lower than $45 \mathrm{mg} / \mathrm{mL}$. The mean apparent efficiency of absorption was $38.10 \%$, with values between $0.02 \%$ and $98.80 \%$. The serum IgG concentration was correlated with the total protein concentration (according to the enzymatic colorimetric method), the gamma-globulin concentration, and the absorption efficiency. The extreme variation on apparent efficiency of absorption may have an effect on the success of PIT. Lambs should consume at least $30 \mathrm{~g}$ of $\operatorname{IgG}$ in the first $24 \mathrm{~h}$ of life to ensure adequate PIT.

Key words: ELISA, gamma-globulin, immunoglobulin $G$, total serum protein

\section{INTRODUCTION}

In ruminants, colostrum is the sole source of initial acquired immunity for the offspring (Stelwagen et al., 2009), with IgG being the major immunoglobulin class present, which ensures protection in early life (Larson et al., 1980). However, the increased abomasal secretions and proteolytic activity of the intestinal mucosa (Kruse, 1983; Bessi et al., 2002), as well as the reduced ability of the cells of the small intestine to absorb immunoglobulin (Quigley, 2001), result in a linear reduction of the IgG absorption efficiency after birth (Kruse, 1970). In fact, the cells of the small intestine in ruminants are able to internalize and transfer colostrum IgG in its intact form to the blood only during the first 24 $\mathrm{h}$ of life (Stott et al., 1979b; Sheldrake and Husband, 1985; Castro-Alonso et al., 2008).

Thus, colostrum should be provided within the shortest time possible after birth to ensure the adequate passive immune transfer (PIT) to lambs. Mellor and Murray (1986) recommended an intake of 180 to 210 $\mathrm{mL}$ of colostrum $/ \mathrm{kg}$ of $\mathrm{BW}$ for lambs born in feedlots or the field during the first $18 \mathrm{~h}$ of life. According to 
Morrical et al. (1995), lambs should receive $10 \%$ of their BW in colostrum within $24 \mathrm{~h}$ after birth.

Passive immune transfer can be assessed through the serum total protein concentration, which reflects the amount of albumin and globulins, although this technique is nonspecific (Flaiban et al., 2009). The confirmatory tests considered the gold standard for IgG measurement include single radial immunodiffusion and ELISA. Enzyme-linked immunosorbent assay offers advantages in terms of cost, time, and ability to quantify the IgG level in a large number of samples at once, and this approach has been used to confirm the diagnosis of failure of PIT (FPIT) in cattle (Weaver et al., 2000; Hurley et al., 2004; Lee et al., 2008). Some authors (McGuire et al., 1983) used reference values in calves to characterize FPIT in lambs, whereas other authors (Hunter et al., 1977; Flaiban et al., 2009; Silva et al., 2009; Turquino et al., 2011) characterized FPIT by serum $\operatorname{IgG}$ concentration $<15 \mathrm{mg} / \mathrm{mL}$. However, no IgG value is universally accepted to characterize FPIT in lambs.

The colostrum and milk composition varies between sheep breeds. Colostral IgG concentration measured by single radial immunodiffusion varied from 60 to $70 \mathrm{mg} /$ $\mathrm{mL}$ in ewes Rambouillet, Targhee, Columbia, and Finn crossbreed (Gilbert et al., 1988), Akkaraman (Maden et al., 2003), and Aragonesa (Loste et al., 2008), while was $79 \mathrm{mg} / \mathrm{mL}$ in the Polypay breed (al-Sabbagh et al., 1995 ) and $125 \mathrm{mg} / \mathrm{mL}$ in the Karakul breed (Hashemi et al., 2008). In the Santa Inês breed, which formed the basis of commercial flocks in Brazil, where they are mainly used for meat production, IgG values measured by radial immunodiffusion were 89.6 and $95.6 \mathrm{mg} / \mathrm{mL}$ in the colostrum from multiparous and primiparous ewes, respectively (Nunes, 2006). In addition, levels of $5.8 \%$ fat, $17.4 \%$ TS, and $11.6 \%$ defatted dry extract were found in the milk of this breed (Ribeiro et al., 2007).

The objectives of this study were to analyze the chemical composition and the IgG concentration of the colostrum, transitional milk, and mature milk of Santa Inês ewes and to evaluate the PIT to lambs through analysis of serum IgG and total protein concentrations at $36 \mathrm{~h}$ after birth.

\section{MATERIALS AND METHODS}

These experiments were performed at the Sheep Husbandry Sector of the Department of Animal Science, Federal University of Lavras (Universidade Federal de Lavras, UFLA), Lavras, Minas Gerais, Brazil. This research site is located at $21^{\circ} 14^{\prime} 43^{\prime \prime} \mathrm{S}, 44^{\circ} 59^{\prime} 59^{\prime \prime} \mathrm{W}$, and altitude of $919 \mathrm{~m}$. The project was approved by the Ethics Committee on Animal Use of UFLA and was registered under protocol number CEUA/UFLA $042 / 10$.

\section{Animals}

Thirty-two Santa Inês sheep between the ages of 1 to $3 \mathrm{yr}$, with a weight of $53.3 \pm 1.7 \mathrm{~kg}($ mean $\pm \mathrm{SE})$ and BCS between 3.0 and 3.5 (scale $0-5$, where $0=$ emaciated and $5=$ very fat; Gordon, 1997), were used to assess the colostrum and milk composition. From the 38 lambs used to evaluate PIT, 21 were from single and 17 from twin pregnancies. One of the lambs from a twin pregnancy was not included in the sampling because it had a low birth weight $(1.690 \mathrm{~kg})$ and dyspnea, followed by prostration; therefore, adequate colostrum feeding and blood collection were not possible.

\section{Sheep Dietary Management}

In the first 4 mo of pregnancy, the ewes were released in a Brachiaria decumbens pasture during the day $(0700$ to $1700 \mathrm{~h}$ ) and were housed during the night (between 1700 and $0700 \mathrm{~h}$ ) in collective pens. Their diet was supplemented with corn silage and concentrate containing soybean meal, corn meal, and minerals; mineral salt was provided ad libitum.

The ewes were confined in a collective stall for the last month of pregnancy and in individual stalls after lambing $(1.0 \times 2.7 \mathrm{~m})$. The sheep were fed a complete diet (Table 1), twice a day, in a sufficient amount to allow at least $10 \%$ leftovers. The leftovers were weighed daily to adjust the amount offered. The diets were prepared according to the recommendations of the NRC (2007) to meet the nutritional requirements of sheep in late pregnancy or early lactation.

\section{Milking}

The ewes were separated from their lambs and milked after birth. An appropriate milking parlor was used, and $5 \mathrm{IU}$ of oxytocin (Oxytocin Forte UCB, Uzinas Chimicas Brasileiras, Jaboticabal, Brazil) was administered intramuscularly to the sheep. The udder was completely milked after disinfection with 5\% iodine solution.

Lambs from 2 ewes were suckled before the first milking, and the colostrum samples from these sheep were not analyzed. The lambs were confined in a small fenced area $(1.0 \times 0.5 \mathrm{~m})$ inside the sheep stall for the first $36 \mathrm{~h}$ after birth to prevent access to the udder, thus enabling the milking of transitional milk. In total, 19, 17 , and 20 samples of transitional milk milked at 12,24 , and $36 \mathrm{~h}$ after birth, respectively, were analyzed. The transitional milk from ewes whose lambs suckled 
Table 1. Ingredients and chemical composition of the diet consumed by the ewes

\begin{tabular}{lcc}
\hline & \multicolumn{2}{c}{ Ratio (\%) } \\
\cline { 2 - 3 } Item & Prepartum & Postpartum \\
\hline Ingredient & 73.5 & \\
Corn silage & 7.0 & 63.7 \\
Soybean meal & 17.3 & 22.2 \\
Corn meal & 2.1 & 12.1 \\
Minerals & & 2.0 \\
Chemical composition & 43.1 & 41.8 \\
DM & 12.4 & 19.1 \\
CP & 35.3 & 29.4 \\
NDF & 8.6 & 6.8 \\
Ash & 4.2 & 5.1 \\
Ether extract & 39.5 & 39.6 \\
NFC &
\end{tabular}

${ }^{1}$ Minerals (Vacci-phos for sheep without copper, Vaccinar, Belo Horizonte, Brazil): $155.0 \mathrm{~g}$ of Ca; $85.0 \mathrm{~g}$ of P; $5.0 \mathrm{~g}$ of Mg; $15.0 \mathrm{mg}$ of $\mathrm{S} ; 140.0 \mathrm{~g}$ of Na; 3,500.0 $\mathrm{mg}$ of Zn; 5,000.0 $\mathrm{mg}$ of $\mathrm{Mg} ; 42.0 \mathrm{mg}$ of I; $15.0 \mathrm{mg}$ of Se; $36.0 \mathrm{mg}$ of Co; 1,000.0 $\mathrm{mg}$ of F; and 1,000.0 $\mathrm{mg}$ of $\mathrm{Mn}$.

${ }^{2} \mathrm{NFC}=\mathrm{DM}-(\mathrm{CP}+\mathrm{NDF}+$ ether extract + ash $)$.

before the sample collection was not considered in the analysis. Samples with insufficient volume or samples that were coagulated or considered unsuitable were not analyzed. The 32 ewes were milked on d 10 after birth.

\section{Chemical Composition Analysis of Colostrum, Transitional Milk, and Mature Milk}

A graduated cylinder was used to determine the amount of colostrum produced. A sample of $50 \mathrm{~mL}$ of colostrum and a sample of $30 \mathrm{~mL}$ of transitional milk and mature milk were collected to analyze the fat, protein, lactose, and defatted dry extract contents. The samples of colostrum were cooled in the refrigerator and sent to the laboratory on the day of collection. The samples of transitional milk and mature milk were stored in vials containing bronopol (2-bromo 2-nitropropane 1,3 diol). Samples of $10 \mathrm{~mL}$ were collected from each milking and frozen at $-20^{\circ} \mathrm{C}$ until assayed for IgG levels.

Due to high viscosity of the colostrum, the chemical composition was determined according to the methodology proposed by Abreu (1999). The titration of 10 $\mathrm{mL}$ of the sample with a $0.111(1 / 9) \mathrm{mol} / \mathrm{L}$ of sodium hydroxide solution, using phenolphthalein as an indicator, was performed to determine the acidity, and the result was expressed in degrees Dornic $\left({ }^{\circ} \mathrm{D}\right)$. The fat content was determined with the Gerber butyrometer method (International Dairy Federation, 1991), and TS were measured using the formula TS $=1.2 \times \mathrm{F}+[2.665$ $\times(100 \times \mathrm{D}-100) / \mathrm{D}]$, in which $\mathrm{F}$ is the percentage of fat in the sample and $\mathrm{D}$ is its density. The density was calculated through the ratio between the colostrum weight (mass) and volume. The total nitrogen content was analyzed by the Kjeldahl method, using $5 \mathrm{~mL}$ of colostrum, catalyst solution (potassium sulfate and copper sulfate), and sulfuric acid. The sample was subsequently distilled and titrated using $1.41 \mathrm{~mol} / \mathrm{L}$ of $\mathrm{HCl}$. The protein percentage was calculated by multiplying the nitrogen content by a factor of 6.35 . The defatted dry extract was determined through the gravimetric method, which involves the loss of moisture and volatiles by drying and weighing the residue obtained. The lactose content was obtained using Fehling's method (AOAC, 1990), which is based on the reduction of cupric and cuprous ions by lactose in an alkaline medium. The chemical composition of transitional milk and mature milk was analyzed through infrared ray absorption using electronic analyzers (Bentley 2000, Bentley Instruments, Chaska, MN).

\section{Colostrum Supply to the Lambs}

Thirty-eight lambs received colostrum artificially in a bottle and were used to analyze the occurrence of FPIT. The first feeding occurred at $40 \pm 15$ (mean \pm standard deviation) minutes after birth, and the colostrum was offered again every $30 \mathrm{~min}$ after the first intake to obtain a volume intake corresponding to $10 \%$ of the lamb's BW. When the colostrum was insufficient, especially in cases of multiple births, the lambs received colostrum from another ewe that produced a sufficient quantity to provide leftovers. The transitional milk milked at 12,24 , and $36 \mathrm{~h}$ after birth was artificially supplied ad libitum in the bottle, and the ingested amount was recorded.

\section{Lamb Blood Collection}

A blood sample of approximately $8 \mathrm{~mL}$ was collected from all lambs at $36 \mathrm{~h}$ after birth by jugular-vein puncture using a $25 \times 7 \mathrm{~mm}$ needle (BD Vacutainer, BD Medical, Juiz de Fora, Brazil) and vacuum bloodcollection tubes without anticoagulant (Vacutainer, Shandong Weigao Group Medical Polymer Co. Ltd., Hong Kong, China). The blood samples were centrifuged at 4,200 $\times g$ for $10 \mathrm{~min}$, and the serum was stored in 1.5-mL polyethylene tubes and frozen at $-20^{\circ} \mathrm{C}$ for subsequent analysis.

\section{Refractometry}

The manual refractometer (RTP-20ATC Refractometer, Instrutherm, São Paulo, Brazil) used for the measurement of total serum protein was initially calibrated with distilled water. Subsequently, a serum aliquot thawed at room temperature was read on a scale from 0 to $12 \mathrm{~g} / \mathrm{dL}$, with $0.2 \mathrm{~g} / \mathrm{dL}$ subdivisions. 
Total Protein, Albumin, and Gamma-Globulin Determination

Enzymatic colorimetric kits (Total Protein, Labtest, Lagoa Santa, Brazil and Albumin, Doles, Goiânia, Brazil) were used to analyze the serum total protein and albumin concentrations. The biuret reagent, consisting of a copper, trisodium citrate, sodium carbonate, and sodium hydroxide solution, was used for determination of the total protein content; this reagent reacts with the proteins in the sample to form a violet-colored complex. Bromocresol green solution buffered at $\mathrm{pH} 4$ was used to determine the albumin concentration because it reacts specifically with albumin to form a green-colored complex, in which the color intensity is proportional to the total protein and serum albumin content. The readings were performed on a spectrophotometer at a wavelength of $550 \mathrm{~nm}$ for total protein and $630 \mathrm{~nm}$ for albumin measurements. The serum gamma-globulin concentration was obtained according to the difference between total protein and albumin values.

\section{Indirect ELISA Test}

Due to the high viscosity of colostrum and transitional milk, a previous preparation was required for the indirect ELISA test, as described below. Frozen samples were thawed in a container with ice and subsequently centrifuged at $490 \times g$ and $4^{\circ} \mathrm{C}$ for $1 \mathrm{~h}$ to precipitate the casein. The supernatant was diluted in a $0.15 \mathrm{M}$ $\mathrm{NaCl}$ solution and $\mathrm{pH} 4.6$, and the solutions were kept overnight at $4^{\circ} \mathrm{C}$. Then, the samples were centrifuged at $11,000 \times g$ for $15 \mathrm{~min}$ at $4^{\circ} \mathrm{C}$, and the supernatant (antibodies) was stored in 1.5-mL polyethylene tubes.

This test was standardized using serial dilutions of sheep IgG (IgG from sheep serum, Sigma-Aldrich Corp., St. Louis, MO). The results enabled the formation of a standard curve for IgG concentrations in the colostrum, transitional milk, mature milk, and serum from lambs.

High-binding plates (Hexis, Jundiaí, SP, Brazil) were initially sensitized with $100 \mathrm{~mL}$ of sample (1:1,000 dilution with carbonate/bicarbonate solution) and then left overnight. The plates were then washed 6 times in a PBS pH 7.4 solution containing $0.05 \%$ Tween 20, blocked with $200 \mu \mathrm{L}$ per well of skim milk blocking solution and incubated at $37^{\circ} \mathrm{C}$ for $2 \mathrm{~h}$. After this procedure, the plates were again washed with washing solution (PBS pH 7.4 with $0.05 \%$ Tween 20) and then subjected to incubation with primary antibody $\left(37^{\circ} \mathrm{C}\right.$ for $\left.1 \mathrm{~h}\right)$, followed by incubation with peroxidaselabeled secondary antibody (anti-sheep IgG-peroxidase, Sigma-Aldrich Corp.) at a 1:40,000 dilution. Next, the plates were washed again before the addition of $100 \mathrm{~mL}$ of chromogenic substrate (Sigma-Fast OPD, SigmaAldrich Corp.) diluted in distilled water. After $15 \mathrm{~min}$, the reaction was blocked with $50 \mu \mathrm{L}$ of $1 \%$ reaction stop solution $(\mathrm{HCl})$. The plates were read using a microplate spectrophotometer with a 490-nm filter.

\section{FPIT Assessment}

The criteria used to identify lambs with FPIT consisted of serum concentrations of IgG below $15 \mathrm{mg} / \mathrm{mL}$ and of total protein below $45 \mathrm{mg} / \mathrm{mL}$ (Feitosa et al., 2001; Turquino et al., 2011).

\section{Apparent Efficiency of Absorption}

The apparent efficiency of absorption (AEA) was calculated using the following formulas described by Quigley and Drewry (1998):

$$
\begin{aligned}
& \operatorname{AEA}(\%)=\text { serum } \operatorname{IgG}(\mathrm{g}) / \operatorname{IgG} \text { intake }(\mathrm{g}) \times 100, \\
& \begin{array}{c}
\text { serum } \operatorname{IgG}(\mathrm{g})=\text { serum } \operatorname{IgG} \text { concentration }(\mathrm{g} / \mathrm{L}) \\
\times \text { serum volume }(\mathrm{L}) .
\end{array}
\end{aligned}
$$

The serum $\operatorname{IgG}$ concentration $(\mathrm{g} / \mathrm{L})$ at $36 \mathrm{~h}$ of life, the serum volume (L) estimated as $7 \%$ of $\mathrm{BW}$ at birth (Quigley and Drewry, 1998), and the IgG intake (g) until $24 \mathrm{~h}$ of age were considered for this analysis. The IgG intake was calculated from the concentration of $\operatorname{IgG}(\mathrm{g} / \mathrm{L})$ in the colostrum and transitional milk collected at 12 and $24 \mathrm{~h}$ and the ingested volume.

\section{Data Analysis}

The colostrum, transitional milk, and mature milk production, the fat, protein, lactose, TS, and defatted dry extract percentages and the IgG concentration in these secretions were analyzed considering the sheep effect as random. Repeated measures analyses were performed using the SAS software (SAS Institute, 2008), considering the following statistical model:

$$
\begin{aligned}
y_{i j k l}= & \mu+\alpha_{i}+\beta_{j}+\tau_{k}+\alpha \beta_{i j}+\alpha \tau_{i k}+\beta \tau_{j k} \\
& +\alpha \beta \tau_{i j k}+\omega_{i j l}+\varepsilon_{i j k l},
\end{aligned}
$$

where $y_{i j k l}$ is the value observed in $l$ th sheep with parity $i$ and BCS $j$ in the time $k ; \mu$ is the constant inherent to each observation; $\alpha_{i}$ is the parity effect $i$, with $i=$ 1,2 , in which $i=1$ for primiparous sheep and $i=2$ for multiparous; $\beta_{j}$ is the BCS effect $j$, with $j=1,2$, in which $j=1$ corresponds to BCS $<2.75$ and $j=2$ to $\mathrm{BCS} \geq 2.75 ; \tau_{k}$ is the time effect $k$, with $k=1, \ldots$, 
5, which correspond to 5 times: $0,12,24,36$, and 240 h after birth; $\alpha \beta_{i j}, \alpha \tau_{i k}, \beta \tau_{j k}$, and $\alpha \beta \tau_{i j k}$ are the double and triple interactions among the factors considered; $\omega_{i j l}$ is the random effect for sheep $l$, which has parity $i$ and $\mathrm{BCS} j$; and $\varepsilon_{i j k l}$ is the experimental error associated with the observation.

Regression models were fitted for the variables production, fat, protein, lactose, TS, defatted dry extract, and IgG as function of the time. The independent variable time (in hours) was transformed to ln (time +1$)$ in the regression study. The time points considered for analysis included $0 \mathrm{~h}$ (immediately after birth) and 12 , 24, 36 and $240 \mathrm{~h}$ after birth. Analyses were performed using the SAS software (SAS Institute, 2008).

The serum concentrations of IgG, total protein (according to the enzymatic colorimetric method and refractometry), albumin, and gamma-globulins were analyzed through ANOVA using the SAS software. The amount of IgG ingested was considered as a covariate in the determination of the serum concentrations of IgG and total protein with the enzymatic colorimetric method. The lamb birth weight and the amount of IgG ingested were considered as covariates in the serum gamma-globulin concentration analysis. The following statistical model was used:

$$
\begin{aligned}
y_{i j k l m}= & \mu+\beta_{1} x_{i j k l m}+\beta_{2} z_{i j k l m}+\tau_{i}+\varepsilon_{j}+\varphi_{k}+\omega_{l}+\tau \varepsilon_{i j} \\
& +\tau \varphi_{i k}+\varepsilon \varphi_{j k}+\tau \omega_{i l}+\varphi \omega_{k l}+\varepsilon \omega_{j l}+\tau \varepsilon \varphi_{i j k}+\tau \varepsilon \omega_{i j l} \\
& +\tau \varphi \omega_{i k l}+\varepsilon \varphi \omega_{j k l}+\tau \varepsilon \varphi \omega_{i j k l}+e_{i j k l m}
\end{aligned}
$$

where $y_{i j k l m}$ is the value observed in $m$ th lamb, of sex $l$, born from the type of pregnancy $k$, of sheep with parity $i$ and $\mathrm{BCS} j \mu$ : constant inherent to each observation; $x_{i j k l m}$ is the lamb birth weight associated with observation $y_{i j k l m} ; \beta_{1}$ is the slope associated with the covariate lamb birth weight; $z_{i j k l m}$ is the lamb IgG intake associated with observation $y_{i j k l m} ; \beta_{2}$ is the slope associated with the covariate lamb $\operatorname{IgG}$ intake; $\tau_{i}$ is the parity effect $i$; with $i=1,2$, in which $i=1$ for primiparous ewes and $i=2$ for multiparous; $\varepsilon_{\mathrm{j}}$ is the BCS effect $j$, with $j=1,2$, in which $j=1$ corresponds to BCS $<2.75$ and $j=2$ corresponds to BCS $\geq 2.75 ; \varphi_{k}$ is the effect of the type of gestation $k$, with $k=1,2$, in which $k=$ 1 for simple pregnancy and $k=2$ for twin pregnancy; $\omega_{l}$ is the effect of lamb sex $l$, with $l=1,2$, in which $l=1$ for female and $l=2$ for male; $\tau \varepsilon_{i j}, \tau \varphi_{i k}, \varepsilon \varphi_{j k}$, $\tau \omega_{i l}, \varphi \omega_{k l}$, and $\varepsilon \omega_{j l}$ are double interactions between the considered factors; $\tau \varepsilon \varphi_{i j k}, \tau \varepsilon \omega_{i j l}, \tau \varphi \omega_{i k l}$, and $\varepsilon \varphi \omega_{j k l}$ are triple interactions between the studied factors; $\tau \varepsilon \varphi \omega_{i j k l}$ is the quadruple interaction between the studied factors; $e_{i j k l m}$ is the experimental error associated with the observation $y_{i j k l m}$.
The following logistic regression was used for the FPIT analysis:

$$
\hat{p}_{i}=\frac{e^{\beta_{0}+\beta_{1} X_{i}}}{1+e^{\beta_{0}+\beta_{1} X_{i}}},
$$

in which $\hat{p}_{i}$ is the estimated probability of FPIT occurrence, $X_{i}$ is the IgG intake in grams, and the constant $e$ is the natural logarithm, equal to 2.7182. Because variation in AEA may affect the acquisition of passive immunity, the serum IgG concentration was calculated by following formula: serum IgG concentration $(\mathrm{g} / \mathrm{L})=$ $[\operatorname{IgG}$ intake $(\mathrm{g}) \times \mathrm{AEA})] /$ serum volume $(\mathrm{L})$, according to Quigley and Drewry (1998). The IgG intake was calculated from the concentration of $\mathrm{IgG}$ in the colostrum and transitional milk collected at 12 and $24 \mathrm{~h}$ and the ingested volume. The serum volume (L) was estimated as $7 \%$ of BW at birth. The criterion used to identify lambs with FPIT consisted of serum IgG concentrations below $15 \mathrm{mg} / \mathrm{mL}$. The data were analyzed using the logistic procedure included in the SAS software.

Pearson correlations were calculated between the colostrum $\operatorname{IgG}$ concentration and the variables of BCS and sheep weight at lambing; between the serum concentrations of $\operatorname{IgG}$, total protein (according to the enzymatic colorimetric method and refractometry), albumin, and gamma-globulin; between the AEA and serum IgG concentration; and between the AEA and the colostrum intake volume as a percentage of $\mathrm{BW}$.

\section{RESULTS AND DISCUSSION}

The colostrum acidity was $41.41 \pm 3.58^{\circ} \mathrm{D}$ (mean \pm $\mathrm{SE}$ ), and the density was $1.12 \pm 0.01 \mathrm{~g} / \mathrm{mL}$. This density value was similar to that reported by Nunes (2006), who observed a colostrum density of $1.14 \pm 0.03 \mathrm{~g} / \mathrm{mL}$ using refractometry.

The colostrum, transitional milk, and mature milk production of the primiparous ewes, as well as the multiparous, did not differ $(P>0.05)$ between BCS categories at lambing. Production was lower in primiparous than in multiparous ewes with BCS $<2.75$, but did not differ between primiparous and multiparous with BCS $\geq 2.75$ (interaction parity and BCS, $P<0.01$, Table 2 ). Possible reasons for this are that first-parity animals are still growing, which adds to their requirements of energy, as related in dairy cows by Roche et al. (2009). The production showed a quadratic behavior with time postpartum $(P<0.01$, Figure 1$)$.

The IgG concentration and the fat, protein, lactose, and defatted dry extract percentages in the colostrum, 
Table 2. Production (mL; means $\pm \mathrm{SE}$ ) according to parity and sheep BCS at lambing

\begin{tabular}{lcc}
\hline & \multicolumn{2}{c}{ BCS category } \\
\cline { 2 - 3 } Parity & $<2.75$ & $\geq 2.75$ \\
\hline Primiparous & $214.5 \pm 80.3^{\mathrm{a}, \mathrm{B}}$ & $361.8 \pm 52.7^{\mathrm{a}, \mathrm{A}}$ \\
Multiparous & $503.1 \pm 71.1^{\mathrm{a}, \mathrm{A}}$ & $378.4 \pm 42.3^{\mathrm{a}, \mathrm{A}}$ \\
\hline
\end{tabular}

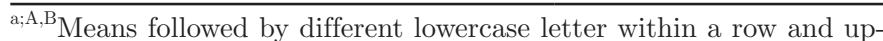
percase letter within a column differ $(P<0.05)$.

transitional milk, and mature milk were not affected $(P$ $>0.05$ ) by the sheep BCS at lambing or by parity (Table 3$)$. The TS percentage was not affected $(P>0.05)$ by parity, but was higher in the colostrum of ewes with $\mathrm{BCS}<2.5$ (interaction $\mathrm{BCS} \times$ time, $P<0.05$ ). This
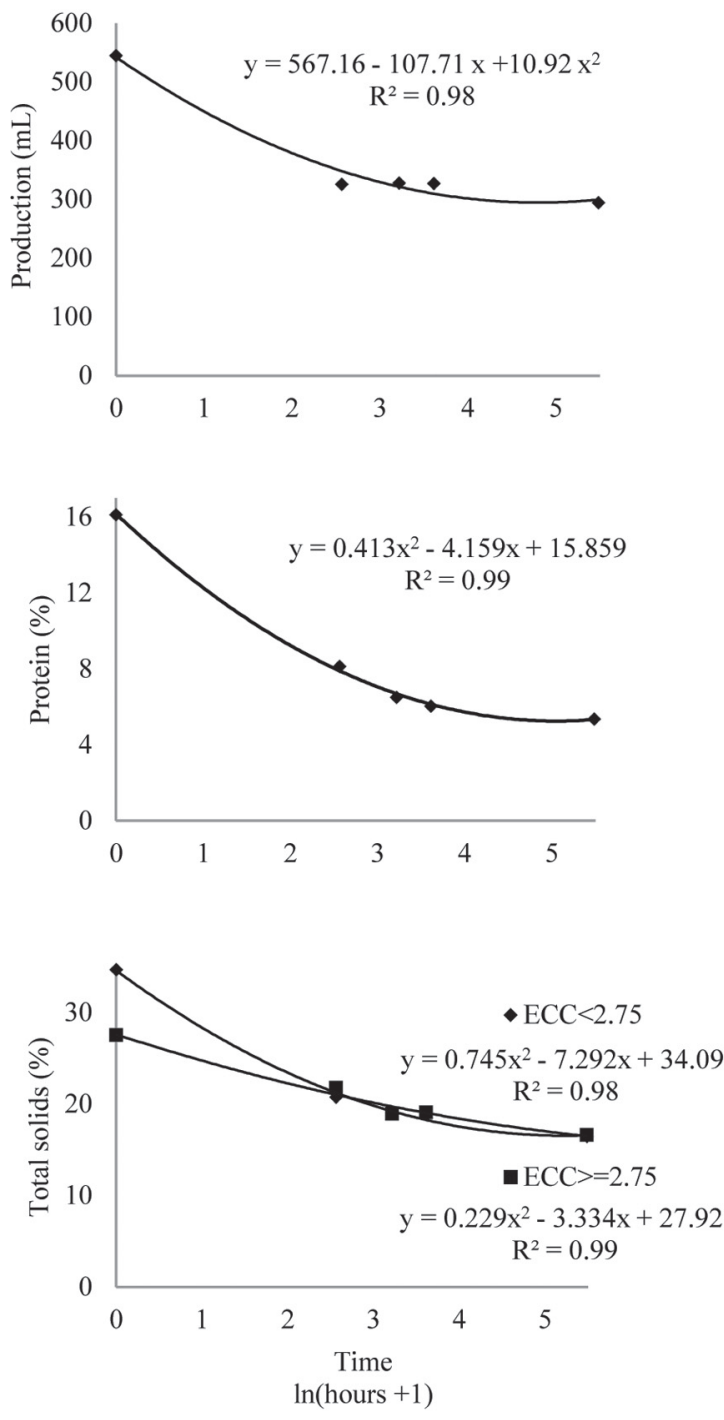

finding was presumed to be attributable to dilutional effects due to the higher volume of colostrum produced by multiparous ewes with $\mathrm{BCS} \geq 2.75$. The fat percentage decreased linearly $(P<0.01)$, the protein, TS, and defatted dry extract percentages showed a quadratic behavior $(P<0.01)$, and the lactose percentage increased linearly $(P<0.01)$ with time postpartum (Figure 1). The fat, protein, TS, and defatted dry extract content decreased by $29.83,62.52,36.58$, and $44.72 \%$ in the first $36 \mathrm{~h}$ after birth, respectively. The lactose levels increased by $29.59 \%$ over the same period.

Similar results were reported by Ciuryk et al. (2004), who observed a decrease of $31.45 \%$ for fat content and $68.66 \%$ for protein when analyzing the colostrum and the transitional milk of Merino sheep during the first 48 $\mathrm{h}$ after the first milking. According to Godden (2008),
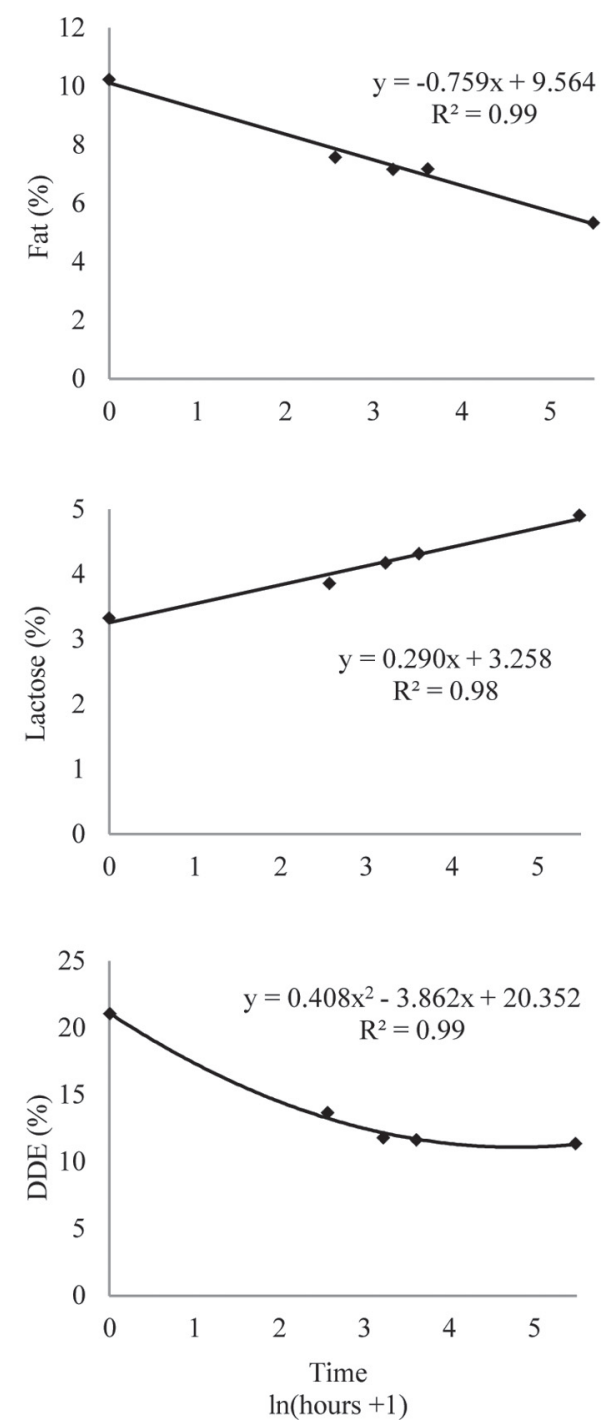

Figure 1. Production and fat, protein, lactose, TS, defatted dry extract (DDE) percentages as a function of time postpartum, considering time $=\ln ($ hours +1$)$. 
Table 3. Immunoglobulin G concentration and fat, protein, lactose, and defatted dry extract (DDE) percentage according to parity and sheep $\mathrm{BCS}$ at lambing (means $\pm \mathrm{SE})^{1}$

\begin{tabular}{lccccc}
\hline Item & $\begin{array}{c}\mathrm{IgG} \\
(\mathrm{mg} / \mathrm{mL})\end{array}$ & $\begin{array}{c}\text { Fat } \\
(\%)\end{array}$ & $\begin{array}{c}\text { Protein } \\
(\%)\end{array}$ & $\begin{array}{c}\text { Lactose } \\
(\%)\end{array}$ & $\begin{array}{c}\text { DDE } \\
(\%)\end{array}$ \\
\hline Parity & & & & & \\
$\quad$ Multiparous & $15.72 \pm 2.65$ & $7.43 \pm 0.52$ & $8.24 \pm 0.40$ & $4.20 \pm 0.24$ & $13.69 \pm 0.44$ \\
$\quad \begin{array}{l}\text { Primiparous } \\
\text { BCS sheep }\end{array}$ & $16.08 \pm 3.10$ & $7.32 \pm 0.39$ & $8.78 \pm 0.76$ & $4.17 \pm 0.27$ & $14.09 \pm 0.74$ \\
$<2.75$ & $16.35 \pm 3.45$ & $8.52 \pm 0.90$ & $10.16 \pm 1.26$ & $4.17 \pm 0.25$ & $15.88 \pm 1.28$ \\
$\geq 2.75$ & $15.45 \pm 2.18$ & $7.13 \pm 0.38$ & $8.44 \pm 0.30$ & $4.11 \pm 0.19$ & $13.68 \pm 0.35$ \\
\hline
\end{tabular}

${ }^{1}$ There was no difference in the IgG concentration and fat, protein, lactose and defatted dry extract percentages in regards to parity or BCS category $(P>0.05)$.

the first-milk colostrum is richer in nutrients and $\mathrm{IgG}$, and a progressive decline occurred in these levels over the next 6 milkings, until the concentrations observed in mature milk are reached. The mature milk composition on d 10 of lactation was similar to that reported by Ribeiro et al. (2007), who observed levels of $5.84 \%$ of fat, $17.40 \%$ of TS, and $11.57 \%$ of defatted solids in the milk of Santa Inês ewes.

The reduction of the IgG concentration in transitional milk and mature milk in relation to colostrum was best explained by the logistic model (Figure 2). Values sharply decline from $6 \mathrm{~h}$ postpartum. At 12 and $24 \mathrm{~h}$ postlambing, the IgG concentrations were 25.36 and $11.73 \mathrm{mg} / \mathrm{mL}$, respectively, and times following tended to reach values close to zero. Similarly, in Karakul ewes, Hashemi et al. (2008) observed that the highest IgG concentration in colostrum was found at 1 $\mathrm{h}$ after lambing but decreased significantly at 12 and $24 \mathrm{~h}$ postlambing. This might be likely due to the postpartum decrease in the ability of mammary gland to transfer IgG from the serum (Hashemi et al., 2008), as occurs in the bovine intestine (Jochims et al., 1994). So, the amount of immunoglobulin available to the lamb is drastically decreased within $12 \mathrm{~h}$ after the first suckling and the lamb failing to suckle during this period may not obtain enough IgG (Mazzone et al., 1999).

Variation was observed among ewes regarding the IgG concentration in the colostrum (1.16 to $60.69 \mathrm{mg} /$ $\mathrm{mL}$ ) and transitional milk (0.005 to $52.25 \mathrm{mg} / \mathrm{mL})$. Significant variation in the colostrum IgG concentration from crossbred sheep was also observed by al-Sabbagh et al. (1995) in samples taken $12 \mathrm{~h}$ after the first milking (76.4 to $36.56 \mathrm{mg}$ of $\mathrm{IgG} / \mathrm{mL}$ ). Additionally, an IgG colostrum concentration higher than that observed in this study $(37.15 \pm 3.82 \mathrm{mg} / \mathrm{mL})$ was reported by Moretti et al. (2010) in colostrum obtained from a colostrum bank $(48.12 \pm 5.0 \mathrm{mg}$ of $\mathrm{IgG} / \mathrm{mL})$ and by Loste et al. (2008) in fresh colostrum from Rasa Aragonesa ewes $(64.18 \mathrm{mg} / \mathrm{mL}$ of $\mathrm{IgG})$. These results suggest that variation in colostrum IgG concentration may be associated with multiple factors, including the analysis method and sheep breed (Gilbert et al., 1988).

No correlation was observed between the colostrum IgG concentration and weight $(\mathrm{r}=0.05, P>0.05)$ or BCS ( $\mathrm{r}=0.05, P>0.05)$ of the sheep at the time of lambing. These results are comparable with those of al-Sabbagh et al. (1995), who found no correlation $(\mathrm{r}=$ $-0.25, P>0.05)$ between the colostrum IgG concentration and BCS of Polypay $\times$ Columbia ewes. Sheep that may have suffered nutritional restriction during pregnancy may produce a lower volume of colostrum (Mellor and Murray, 1985, 1986) but without a reduced IgG concentration (al-Sabbagh et al., 1995; Nunes, 2006; Hashemi et al., 2008; Swanson et al., 2008).

The parity, sheep BCS at lambing, type of pregnancy, and lamb sex did not affect $(P>0.05)$ the serum concentrations of $\operatorname{IgG}$, total protein (according to the enzymatic colorimetric method or refractometry), albumin, or gamma-globulin in lambs (Table 4). Turquino et al. (2011) also found no difference in serum IgG, total pro-

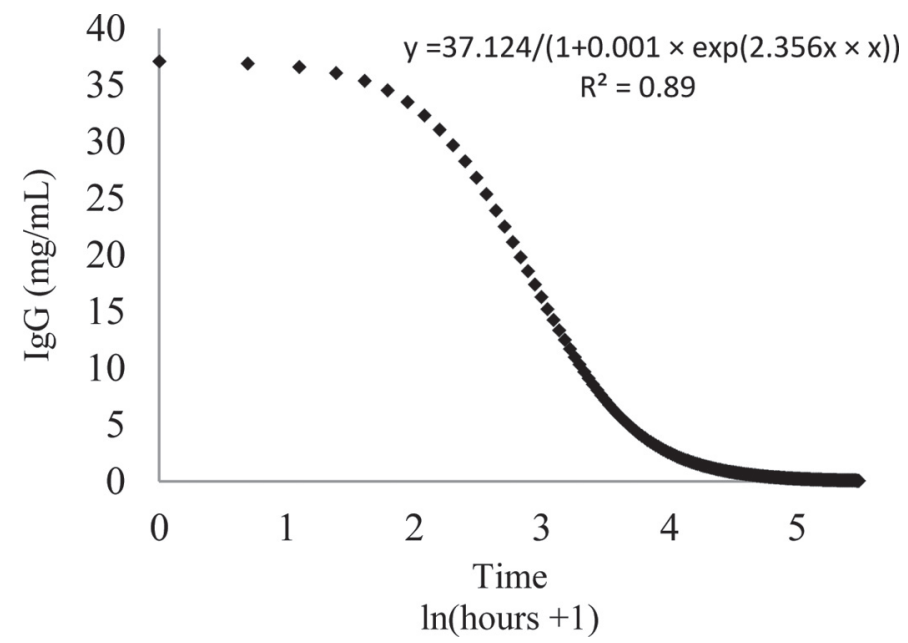

Figure 2. Immunoglobulin G concentration as a function of time postpartum, considering time $=\ln ($ hours +1$)$. 
Table 4. Effect of factors related to ewes and lambs on serum concentrations (means \pm SE) of IgG, total protein (according to colorimetry or refractometry), albumin, or gamma-globulin in lambs ${ }^{1}$

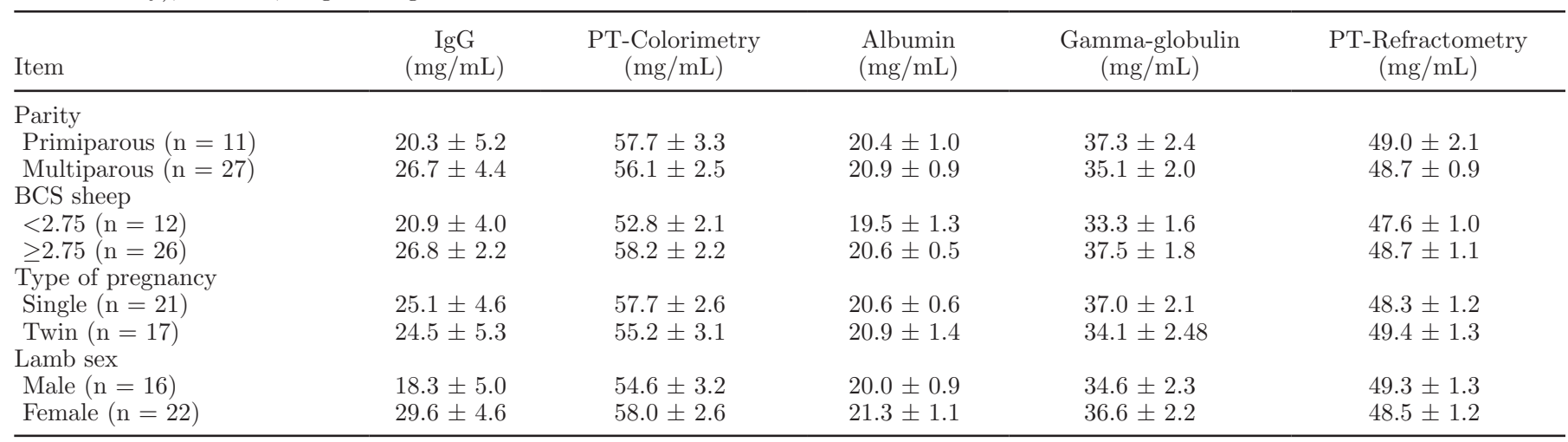

${ }^{1}$ No difference was observed in the serum concentrations of IgG, PT (total protein according to colorimetry or refractometry), albumin, or gamma-globulin with regard to parity, BCS category, type of pregnancy, or lamb sex $(P>0.05)$.

tein, and gamma-globulin concentrations in lambs from ewes of different parity. According to these previous authors, the parity did not seem to be important in the success or failure of PIT. Other authors have also reported no relationship between parity and serum IgG concentration in lambs (Gilbert et al., 1988; Ahmad et al., 2000).

In addition, no distinction was found between lambs from single and twin pregnancies in relation to the colostrum and transitional milk supply, which may have contributed to the lack of any observed differences in serum IgG, total protein, albumin, and gamma-globulin concentrations. Lambs from single pregnancies weighed $4.11 \pm 0.16 \mathrm{~kg}$ (mean $\pm \mathrm{SEM})$ and ingested $715.71 \pm$ $77.52 \mathrm{~mL}$ of colostrum and transitional milk, leading to the total consumption of $17.95 \pm 3.07 \mathrm{~g}$ of $\mathrm{IgG}$ in the first $24 \mathrm{~h}$ of life. The twin lambs weighed $3.51 \pm 0.14 \mathrm{~kg}$ and ingested $546.67 \pm 44.82 \mathrm{~mL}$ of colostrum and transitional milk, which was calculated as the equivalent of $16.79 \pm 2.49 \mathrm{~g}$ of IgG in the same period.

In contrast to the current study, Nunes (2006) reported differences between serum IgG concentrations (mean $\pm \mathrm{SE}$ ) in lambs from single pregnancies (52.8 \pm $3.79 \mathrm{mg} / \mathrm{mL})$ and twin pregnancies $(35.3 \pm 3.18 \mathrm{mg} /$ $\mathrm{mL}$ ), and the study by Turquino et al. (2011) reported variations in serum IgG concentrations of $33.18 \pm 11.77$ $\mathrm{mg} / \mathrm{mL}$ in single lambs and $28.20 \pm 12.06 \mathrm{mg} / \mathrm{mL}$ in twins, as well as variations in serum gamma-globulin and total protein concentrations. However, in both studies, the lambs were suckled colostrum directly from the ewe. According to Turquino et al. (2011), the colostrum volume produced by sheep may be sufficient to enable successful PIT to a single lamb; however, the risk of FPIT increases in the case of twins. It has also been observed that FPIT occurrence is more likely in lambs of twin compared with single pregnancies (Christley et al., 2003; Nunes, 2006).
Similar to this study, Ahmad et al. (2000) found no difference in serum IgG concentrations between male $(37.36 \pm 2.58 \mathrm{mg} / \mathrm{mL}$; mean $\pm \mathrm{SE})$ and female $(36.53 \pm$ $2.29 \mathrm{mg} / \mathrm{mL}$ ) Pak-Karakul lambs. Gilbert et al. (1988) also found no difference in IgG concentrations between male $(32 \pm 0.9 \mathrm{mg} / \mathrm{mL})$ and female $(33 \pm 0.9 \mathrm{mg} / \mathrm{mL})$ lambs in a study examining various breeds (Polypay, Rambouillet, Targhee, Columbia, Finn, and half-Finn). Nunes (2006) and Turquino et al. (2011) also found no differences in serum IgG concentration between male and female lambs.

According to Turquino et al. (2011), no universally accepted critical value of serum IgG concentration exists to characterize the FPIT condition in lambs. However, the cut-off value of $15 \mathrm{mg}$ of $\mathrm{IgG} / \mathrm{mL}$ of serum has been adopted by many authors (Hunter et al., 1977; Flaiban et al., 2009; Silva et al., 2009; Turquino et al., 2011), with the assumption that PIT is not successful below this value. Considering this criterion and the level of IgG intake in grams, adequate PIT was observed in lambs that ingested at least $30 \mathrm{~g}$ of $\mathrm{IgG}$ [adjusted odds ratio and $95 \%$ confidence limits $=0.83$ (0.73 to 0.96 ), $P<0.01$, Figure 3].

In this study, $39.5 \%$ of the lambs demonstrated FPIT when a serum IgG concentration lower than 15 $\mathrm{mg} / \mathrm{mL}$ was considered. These results are higher than those reported by Turquino et al. (2011), who observed FPIT in $12.4 \%$ of lambs when using the single radial immunodiffusion technique. Our delivery of an artificial supply of colostrum in a bottle could have influenced the absorption of $\operatorname{IgG}$ and consequently resulted in a higher FPIT occurrence. The establishment of the mother-child relationship also appears to play a key role in PIT in lambs (Halliday and Williams, 1979). Stott et al. (1979a) reported that calves that suckled from the mother achieved substantially higher serum IgG concentrations per colostrum unit consumed than 


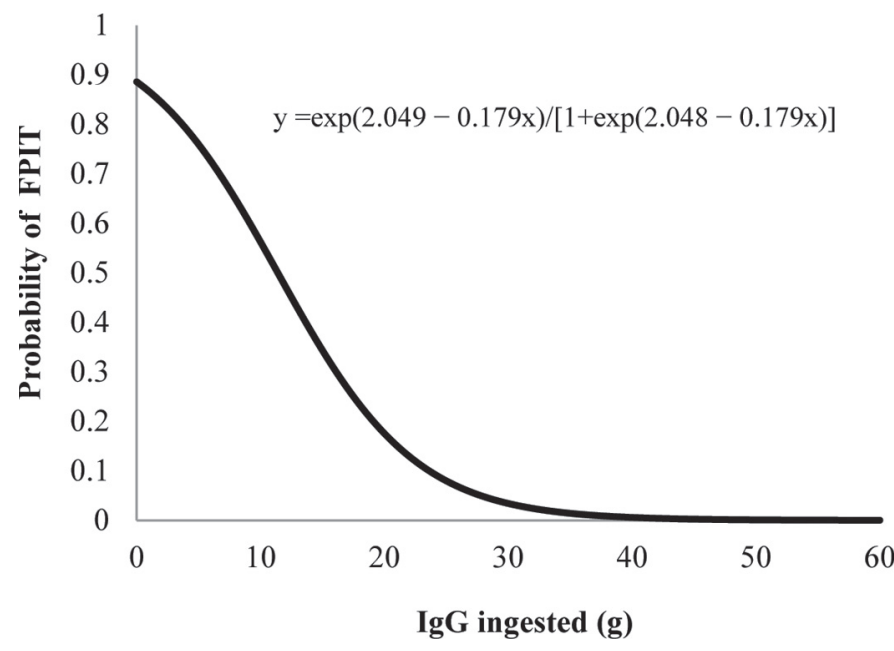

Figure 3. Probability of FPIT occurrence in lambs according to the amount of IgG ingested. Adjusted OR (95\% confidence limits) $=$ $0.83(0.73-0.96), P<0.01$.

calves that received colostrum in a bottle. However, although the efficiency of $\operatorname{IgG}$ absorption is greater when the newborn suckled colostrum directly from the mother, the risk of insufficient consumption can override this potential benefit (Davis and Drackley, 1998).

The frequencies of AEA in lambs are presented in the Table 5. Different classes were defined because this variable has continuous values between 0 and $100 \%$. The average AEA was $38.10 \%$, with values between 0.02 and $98.80 \%$. However, despite of the huge variation of AEA, it was observed that $50.0 \%$ of the lambs had AEA less than $33.4 \%$, and $65.8 \%$ of the lambs had AEA less than $50 \%$. A minority of lambs had AEA above $83.5 \%$. Considering that the variation in AEA may affect the acquisition of PIT (Quigley and Drewry, 1998), this extreme variation in AEA in lambs may be as or more important than the colostrum quality. So, FPIT may occur when good quality colostrum is fed, but the AEA is low.

Many factors can influence AEA in calves, such as age at first colostrum feeding, sex, breed, method of colostrum feeding, metabolic state (Quigley and Drewry, 1998), and concentration of IgG in colostrum (Stott and Fellah, 1983). Estimates of apparent efficiency of IgG absorption in calves are also remarkably variable (Matte et al., 1982; Abel Francisco and Quigley, 1993). Matte et al. (1982) reported that when colostrum was given $6 \mathrm{~h}$ after birth, the AEA was $65.8 \%$; however, this percentage declined rapidly to reach $6.0 \%$ when colostrum was given at the age $48 \mathrm{~h}$. An AEA as high as $88 \%$ at $6 \mathrm{~h}$ postfeeding was reported for Cruywagen (1990) in calves that received colostrum $1 \mathrm{~h}$ postpartum. In this study, the first colostrum feeding occurred on aver-
Table 5. Observed frequency according to the apparent efficiency absorption class of IgG in lambs

\begin{tabular}{lcc}
\hline Class AEA $(\%)$ & $\begin{array}{c}\text { Absolute } \\
\text { frequency }\end{array}$ & $\begin{array}{c}\text { Relative } \\
\text { frequency }(\%)\end{array}$ \\
\hline$<16.8$ & 11 & 28.95 \\
$(16.8 ; 33.4)$ & 8 & 21.05 \\
$(33.4 ; 50.1)$ & 6 & 15.79 \\
$(50.1 ; 66.8)$ & 6 & 15.79 \\
$(66.8 ; 83.5)$ & 5 & 13.16 \\
$>83.5$ & 2 & 5.26 \\
Total & 38 & 100 \\
\hline
\end{tabular}

${ }^{1}$ Mean \pm standard error: $38.10 \pm 4.69$; minimum: 0.02; maximum: 98.80; median: 34.48 .

age 40 min after birth, and the colostrum was offered again every $30 \mathrm{~min}$ after the first intake pretending to reach a volume intake corresponding to $10 \%$ of the lamb's BW. So, the immediate colostrum feeding may have contributed to the high AEA values observed.

The percentage of AEA was correlated with lamb serum IgG $(\mathrm{r}=0.73, P<0.05)$. However, the percentage of AEA was not correlated to the colostrum ingestion expressed as a percentage of the lamb's BW at birth (r $=0.07, P>0.05$ ), showing that an increased volume of colostrum ingested does not always guarantee good absorption efficiency. Moreover, the AEA can be related to the quality of colostrum ingested (Stott and Fellah, 1993). In fact, when fixed volumes of colostrum were fed to neonatal calves, higher serum IgG concentrations were achieved with high immunoglobulin colostrum than with low immunoglobulin colostrum (Morin et al., 1997; Jaster, 2005). Additionally, in goat kids, Castro et al. (2005) suggested a positive correlation between IgG colostrum concentration and absorption and Rodrígues et al. (2009) observed that increasing the immunoglobulin concentration in atomized colostrum paste improved immunoglobulin absorption when the same total amount of immunoglobulins was fed. According to Moretti et al. (2010), the total mass of IgG ingested by the newborn lamb was the main determinant in the absorptive efficiency and serum concentration of this immunoglobulin.

Adopting the criterion proposed by Feitosa et al. (2001), where, in the absence of dehydration conditions, a serum total protein concentration below 45 $\mathrm{mg} / \mathrm{mL}$ is indicative of FPIT, $21 \%$ of the lambs in this study demonstrated FPIT. However, due to the low sensitivity of this test, it is possible that the serum total protein concentration was overestimated and thus the percentage of animals with FPIT would be greater than $21 \%$.

The correlation between serum IgG and total protein concentration determined using the biuret technique was positive but low $(\mathrm{r}=0.44, P<0.05)$, and this 
result contradicts that reported by Turquino et al. (2011), who observed a higher correlation $(\mathrm{r}=0.64, P$ $<0.001)$ between these 2 methods. In addition, the serum gamma-globulin concentration was correlated with the IgG concentration $(\mathrm{r}=0.51, P<0.05)$, although the serum total protein concentration determined by refractometry was not correlated with that determined using the biuret technique $(P<0.05)$ or with the serum IgG concentration $(P>0.05)$.

\section{CONCLUSIONS}

The IgG concentrations in colostrum and transitional milk did not differ between primiparous and multiparous ewes or between ewes with high and low BCS. Decreased levels of nutrients and IgG were found in transitional milk and mature milk compared with the colostrum. However, parity, BCS, type of pregnancy of the ewe, and sex of the lamb did not affect the lambs' serum $\operatorname{IgG}$, total protein, albumin, and gamma-globulin concentrations. The apparent efficiency of IgG absorption in lambs is remarkably variable and may have an effect upon the success of PIT. According to results, to ensure successful PIT, lambs should consume at least $30 \mathrm{~g}$ of IgG during the first $24 \mathrm{~h}$ of life.

\section{ACKNOWLEDGMENTS}

The present study was funded by the Minas Gerais Research Foundation (Fundação de Amparo à Pesquisa do Estado de Minas Gerais, or FAPEMIG) and the National Council for Scientific and Technological Development (Conselho Nacional de Desenvolvimento Científico e Tecnológico, or $\mathrm{CNPq}$ ). The authors thank the Group of Studies in Nutrition and Feeding of Ruminants (UFLA, Lavras, Brazil) for helping in the field experiment.

\section{REFERENCES}

Abel Francisco, S. F., and J. D. Quigley. 1993. Serum immunoglobulin concentrations after feeding maternal colostrum or maternal colostrum plus colostral supplement to dairy calves. Am. J. Vet. Res. 54:1051-1054.

Abreu, L. R. 1999. Tecnologia de leite e derivados. Universidade Federal de Lavras, Lavras, Brazil.

Ahmad, R., A. Khan, M. T. Javed, and I. Hussain. 2000. The level of immunoglobulins in relation to neonatal lamb mortality in PakKarakul sheep. Vet. Arhiv. 70:129-139.

al-Sabbagh, T. A., L. V. Swanson, and J. M. Thompson. 1995. The effect of ewe body condition at lambing on colostral immunoglobulin G concentration and lamb performance. J. Anim. Sci. 73:2860-2864.

Association of Analytical Chemists. 1990. Official Methods of Analysis. Vol. I. 15th ed. Assoc. Off. Anal. Chem., Arlington, VA.

Bessi, R., P. Pauletti, R. D. D'Arce, and R. M. Neto. 2002. Absorção de anticorpos do colostro em bezerros I. Estudo no intestino delgado proximal. R. Bras. Zootec. 31:2314-2324.
Castro, N., J. Capote, S. Alvarez, and A. Arguello. 2005. Effects of lyophilized colostrum and different colostrum feeding regimens on passive transfer of immunoglobulin $\mathrm{G}$ in Majorera goat kids. J. Dairy Sci. 88:3650-3654.

Castro-Alonso, N., J. Capote, A. Morales-delaNuez, I. Moreno-Indias, D. Sanchez-Macias, P. Herraez, and A. Arguello. 2008. Short communication: Apoptosis regulates passive immune transfer in newborn kids. J. Dairy Sci. 91:2086-2088.

Christley, R. M., K. L. Morgan, T. D. Parkin, and N. P. French. 2003. Factors related to the risk of neonatal mortality, birth-weight and serum immunoglobulin concentrations in lambs in the UK. Prev. Vet. Med. 57:209-226.

Ciuryk, S., E. Molik, U. Kaczor, and G. Bonczar. 2004. Chemical composition of colostrums and milk of polish merino sheep lambing at different times. Archiv. Tierz. 47:129-134.

Cruywagen, C. W. 1990. Effect of curd forming of colostrum on absorption of immunoglobulin G in newborn calves. J. Dairy Sci. $73: 3287-3290$

Davis, C. L., and J. K. Drackley. 1998 The Development, Nutrition and Management of the Young Calf. Iowa State University Press, Ames.

Feitosa, F. L. F., E. H. Birgel, R. M. S. Mirandola, and S. H. V. Perri. 2001. Diagnóstico de falha de transferência de imunidade passiva em bezerros através da determinação de proteína total e de suas frações eletrofroréticas, imunoglobulinas G e M e da atividade da gama glutamiltransferase no soro sanguíneo. Cienc. Rural. 31:251-255.

Flaiban, K. K. M. C., M. R. S. Balarin, E. L. A. Ribeiro, F. A. B. Castro, R. M. Mori, and J. A. N. Lisboa. 2009. Transferência de imunidade passiva em cordeiros cujas mães receberam dietas com diferentes níveis de energia ou proteína no terço final da gestação. Cienc. Anim. Bras. Accessed Dec. 13, 2011. http://www.revistas. ufg.br/index.php/vet/article/view/7746/5526.

Gilbert, R. P., C. T. Gaskings, and J. K. Hillers. 1988. Genetic and environmental factors affecting immunoglobulin G1 concentrations in ewe colostrum and lamb serum. J. Anim. Sci. 66:855-863.

Godden, S. 2008. Colostrum management for dairy calves. Vet. Clin. North Am. Food Anim. Pract. 24:19-39.

Gordon, I. 1997. Controlled Reproduction in Sheep and Goats. Vol. 2. CAB International, New York, NY.

Halliday, R., and M. R. Williams. 1979. The absorption of immunoglobulin from colostrum by bottle fed lambs. Ann. Rech. Vet. $10: 549-556$

Hashemi, M., M. J. Zamiri, and M. Safdarian. 2008. Effects of nutritional level during late pregnancy on colostral production and blood immunoglobulin levels of Karakul ewes and their lambs. Small Rumin. Res. 75:204-209.

Hunter, A. G., J. K. Reneau, and J. B. Williams. 1977. Factors affecting IgG concentration in day-old lambs. J. Anim. Sci. 45:11461151.

Hurley, I. P., R. C. Coleman, H. E. Ireland, and J. H. Williams. 2004. Measurement of bovine IgG by indirect competitive ELISA as a means of detecting milk adulteration. J. Dairy Sci. 87:543-549.

International Dairy Federation. 1991. Fat content in milk-Butyrometric method. Standard 152. IDF, Brussels, Belgium.

Jaster, E. H. 2005. Evaluation of quality, quantity, and timing of colostrum feeding on immunoglobulin G1 absorption in Jersey calves. J. Dairy Sci. 88:296-302.

Jochims, K., F. J. Kaup, W. Drommer, and M. Pickel. 1994. An immunoelectron microscopic investigation of colostral IgG absorption across the intestine of newborn calves. Res. Vet. Sci. 57:75-80.

Kruse, P. E. 1983. The importance of colostral immunoglobulins and their absorption from the intestine of the newborn animals. Ann. Rech. Vet. 14:349-353.

Kruse, V. 1970. Absorption of immunoglobulin from colostrum in newborn calves. Anim. Prod. 12:627-638.

Larson, B. L., H. L. Heary Jr., and J. E. Devery. 1980. Immunoglobulin production and transport by the mammary gland. J. Dairy Sci. 63:665-671.

Lee, S. H. J., J. Aaekal, and C. S. Bae. 2008. Enzyme-linked immunosorbent assay, single radial immunodiffusion, and indirect methods 
for the detection of failure of transfer of passive immunity in dairy calves. J. Vet. Intern. Med. 22:212-218.

Loste, A., A. Ramos, and L. M. Férnandez. 2008. Effect of colostrum treated by heat on immunological parameters in newborn lambs. Livest. Sci. 117:176-183.

Maden, M., V. Altunok, F. M. Birdane, V. Aslan, and M. Nizamlioglu. 2003. Blood and colostrum/milk serum $\gamma$-glutamyltransferase activity as a predictor of passive transfer status in lambs. J. Vet. Med. B 50:128-131.

Matte, J. J., C. L. Girard, J. R. Seoane, and G. J. Brisson. 1982. Absorption of colostral immunoglobulin $\mathrm{G}$ in the newborn dairy calf. J. Dairy Sci. 65:1765-1770.

Mazzone, M. M., D. W. Holocombe, C. J. Ackerman, C. E. Balok, A Mendoza-Reyes, and D. M. Hallford. 1999. Effect of short-term protein supplementation on colostrum characteristics and immunoglobulin $\mathrm{G}$ concentrations in colostrum of ewe and lamb serum. Sheep Goat Res. J. 15:64-73.

McGuire, T. C., J. Regnier, T. Kellom, and N. Gates. 1983. Failure in passive transfer of immunoglobulin G1 to lambs: Measurement of immunoglobulin G1 in ewe colostrums. Am. J. Vet. Res. 44:1064-1067.

Mellor, D. J., and L. Murray. 1985. Effects of maternal nutrition on udder development during late pregnancy and on colostrum production in Scottish Blackface ewes with twin lambs. Res. Vet. Sci. $39: 230-234$

Mellor, D. J., and L. Murray. 1986. Making the most of colostrum at lambing. Vet. Rec. 118:351-353.

Moretti, D. B., L. P. Kindlein, P. Pauletti, and R. Machado-Neto. 2010. IgG absorption by Santa Ines lambs fed Holstein bovine colostrum or Santa Ines ovine colostrum. Animal 4:933-937.

Morin, D. E., G. C. McCoy, and W. L. Hurley. 1997. Effects of quality, quantity, and timing of colostrum feeding and addition of a dried colostrum supplement on immunoglobulin G1 absorption in Holstein bull calves. J. Dairy Sci. 80:747-753.

Morrical, D., N. R. Hartwig, and C. Youngs. 1995. Colostrum and health of newborn lambs. Sheep Management. Fact sheet, 12. Iowa State University, Ames.

NRC. 2007. Nutrient Requirements of Small Ruminants. National Academy, Washington, DC.

Nunes, A. B. V. 2006. Estudo da transmissão da imunidade passiva e da mortalidade em cordeiros mestiços de Santa Inês, na região Norte de Minas Gerais. 2006. 83 p. Dissertação (Mestrado em Medicina Veterinária), Universidade Federal de Minas Gerais, Belo Horizonte, Brazil.

Quigley, J. 2001. Colostrum Feeding - How much is enough? Accessed Jul. 10, 2011. http://www.calfnotes.com.

Quigley, J. D., and J. J. Drewry. 1998. Nutrient and immunity transfer from cow to calf pre- and postcalving. J. Dairy Sci. 81:2779-2790.
Ribeiro, L. C., J. R. O. Pérez, P. H. A. Carvalho, F. F. Silva, J. A. Muniz, G. M. Oliveira-Júnior, and N. V. Souza. 2007. Produção, composição e rendimento em queijo do leite de ovelhas Santa Inês tratadas com ocitocina. R. Bras. Zootec. 36:438-444.

Roche, J. R., N. C. Friggens, J. K. Kay, M. W. Fisher, K. J. Stafford, and D. P. Berry. 2009. Invited review: Body condition score and its association with dairy cow productivity, health, and welfare. J. Dairy Sci. 92:5769-5801.

Rodríguez, C., N. Castro, J. Capote, A. Morales-delaNuez, I. MorenoIndias, D. Sanchez-Macias, and A. Arguello. 2009. Effect of colostrum immunoglobulin concentration on immunity in Majorera goat kids. J. Dairy Sci. 92:1696-1701.

SAS Institute. 2008. SAS/STAT User's Guide. Version 8. Cary. Software.

Sheldrake, R. F., and A. J. Husband. 1985. Immune defences at mucosal surfaces in ruminants. J. Dairy Res. 52:599-613.

Silva, D. F. M., J. N. Costa, A. L. Araújo, V. S. Carvalho, A. P. C Peixoto, L. O. Alves, and M. M. Ferreira. 2009. Falha da transferência da imunidade passiva em cordeiros mestiços (Santa Inês $x$ Dorper): Efeito no proteinograma e taxa de mortalidade do nascimento até o desmame. Cien. Ani. Bras. 1:158-163.

Stelwagen, K., E. Carpenter, B. Haigh, A. Hodgkinson, and T. T. Wheeler. 2009. Immune components of bovine colostrum and milk. J. Anim. Sci. 87(Suppl.):3-9.

Stott, G. H., and A. Fellah. 1983. Colostral immunoglobulin absorption linearly related to concentration for calves. J. Dairy Sci 66:1319-1328.

Stott, G. H., D. B. Marx, and B. E. Menefee. 1979a. Colostral immunoglobulin transfer in calves. IV. Effect of suckling. J. Dairy Sci. 62:1908-1913.

Stott, G. H., D. B. Marx, B. E. Menefee, and G. T. Nightengale 1979b. Colostral immunoglobulin transfer in calves I. Period of absorption. J. Dairy Sci. 62:1632-1638.

Swanson, T. J., C. J. Hammer, J. S. Luther, D. B. Carlson, J. B. Taylor, D. A. Redmer, T. L. Neville, J. J. Reed, L. P. Reynolds, J. S. Caton, and K. A. Vonnahme. 2008. Effects of gestational plane of nutrition and selenium supplementation on mammary development and colostrum quality in pregnant ewe lambs. J. Anim. Sci. $86: 2415-2423$.

Turquino, C. F., K. M. C. Flaiban, and J. A. N. Lisbôa. 2011. Transferência de imunidade passiva em cordeiros de corte manejados extensivamente em clima tropical. Pesqui. Vet. Bras. 31:199-205.

Weaver, D. M., J. W. Tyler, D. C. Vanmetre, D. E. Hostetler, and G. M. Barrington. 2000. Passive transfer of colostral immunoglobulins in calves. J. Vet. Intern. Med. 14:569-577. 